\title{
Information and communication technologies: Use and factors for success amongst academics in private and public universities in Nigeria
}

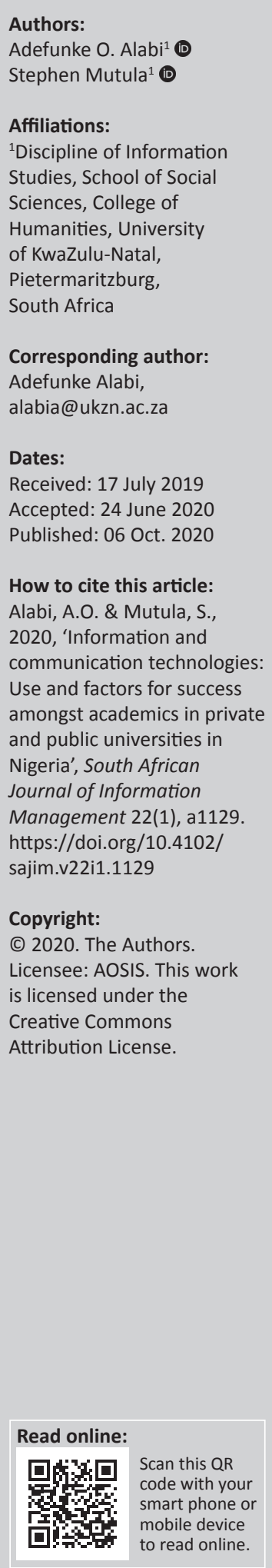

Background: The higher education sector is making a conscious effort to integrate information and communication technologies (ICTs) into the academe with a view to improving teaching, learning and access to knowledge. Unfortunately, the use of ICTs in teaching by academics in Nigerian universities is far below expectation.

Objectives: The aim of this article was to report on a study that examined the underlying factors determining the use of ICTs in teaching by academics in private and public universities in Nigeria by using the unified theory of acceptance and use of technology (UTAUT) as a theoretical lens.

Method: A mixed method approach involving the use of questionnaires and semi-structured interviews was adopted for the study. Data were collected from 267 academics in 3 faculties and 10 key informants who were in managerial positions at the University of Ibadan and Covenant University.

Results: Regression analyses indicated that only facilitating conditions (FCs) ( $\beta=-0.345$, $t=-3.221, p=0.002$ ) have significant influence on the use of ICT in teaching at the University of Ibadan. However, both effort expectancy (EE) $(\beta=0.380, t=3.116, p=0.003)$ and FCs ( $\beta=-0.281, t=-2.327, p=0.023$ ) have significant influence on the use of ICT by academics in Covenant University. The qualitative study explicates these factors: institutional policy, technological infrastructure, simplicity of use, fund and organisational support as success factors for ICT use in teaching. Further findings revealed that age had an effect on EE and FCs amongst academics at the University of Ibadan, but out of all the demographic factors, age emerged as the only variable that had an effect on social influence amongst academics in Covenant University.

Conclusion: The study concludes that stakeholders in higher institutions should give adequate attention to these underlying factors: FCs and EE for optimal success of ICT use in teaching. The findings of this study have far-reaching implications for policy makers within the educational environs and intervention strategies on the part of the university stakeholders in supporting ICT use in teaching.

Keywords: information and communication technologies; ICT use; academics; universities; UTAUT; e-learning; Nigeria.

\section{Introduction}

Information and communication technologies (ICTs) provide limitless opportunities for universities in developing countries to overcome many of the impediments to the successful delivery of higher education (Njoku 2015). The term ICT denotes a wide array of digital technologies used in the creation, processing and transmission of information (Mbatha, Ocholla \& Roux 2011). Examples include computers and their peripheral devices, radio, television, mobile phones, the Internet, Web 2.0 tools, communication technologies, databases, word processors, databases and learning management systems (LMSs). The advent of ICTs and their application in different sectors of life has not just turned the world into a global village, but also transmuted the mode of access to information and how academics in universities worldwide use information in teaching' (Okon, Ngulube \& Onyancha 2014:52). This study operationalises ICTs as all forms of digital technologies used in education to significantly change the traditional mode of teaching in all higher institutions of learning. 
Information and communication technologies' diffusion into higher education can be found in infrastructural development, equipping lecture theatres with the latest multimedia facilities and establishment of centres for ICT and ICT policy (Willis et al. 2013). Moreover, Miller (2017) explained that the United States government supported ICT use in teaching as far back as 1990. There is also the prevalence of extensive training in the form of short courses, seminars and workshops on digital literacy and pedagogical use of various learning (Almpanis 2015). Researchers have assessed the extent to which universities in the United Kingdom, United States of America and Saudi Arabia have tried to infuse ICT into teaching and learning (Alhabeeb \& Rowley 2017; Barrette 2015; Buchanan, Sainter \& Saunders 2013).

Information and communication technology uptake in Nigeria began in 1999 with the African Information Society Initiative (AISI) action plan of 1999 known as National Information and Communication Infrastructure (Ibara 2014). This was followed by the approval of a national policy on ICT by the Federal government in 2001 and establishment of initiatives such as National Information Technology Development Agency (NITDA), Education Trust Fund (ETF) and School Net Nigeria (Mattheew, Joro \& Manasseh 2015). With these initiatives, ICTs such as computers and other various hardware, mobile phones, the Internet and software are now available in Nigerian universities, government departments and their parastatals, industries and banks (Ibara 2014). The potential for ICT-based teaching is supported by numerous factors such as the Internet, broadband connectivity, mobile telephones and networked computers (Lawal, Chatwin \& Hasan 2018). There have also been a series of initiatives on the part of government through the Nigerian Universities Commission (NUC) to ensure that there are ICT facilities such as computers, interactive boards, multimedia projectors and the LMS in Nigerian universities (Gambari \& Okoli 2007).

Despite the relevance of ICTs in the academic success of the students, Yushau and Nannim (2018) noted that there is under-utilisation of ICTs for teaching purposes amongst academics in terms of diversity, frequency and pace. Moreover, previous related studies relied majorly on quantitative approach (Alharbi \& Drew 2014; Ntemana \& Olatokun 2012). This study differentiates itself from previous studies through a combination of quantitative and qualitative research methods to understand the underlying success factors for ICT use in teaching in a developing nation such as Nigeria.

\section{Purpose of the study}

The study reported on in this article examines the factor(s) with the most significant influence on ICT use in teaching amongst academics in public and private university in Nigeria. Without identifying the decisive factors affecting ICT use in teaching by academics, efforts by stakeholders in the education sector on ICT policy formulation will remain futile. The study would be beneficial to university stakeholders in developing a reform agenda necessary for making the university environment more enabling for academics to integrate ICT into teaching. Moreover, the result of this study will add to the body of existing literature on technology adoption, acceptance, use and success of information system (IS).

\section{Research question}

This research question was developed to guide this study: What are the underlying factor(s) for ICT use in teaching amongst academics in public and private universities in Nigeria?

\section{Research hypothesis}

Demographic variables (age, gender and academic qualification) have no effect on the determinants of ICT use in teaching amongst academics.

\section{Literature review}

The use of ICT in teaching is an integral part of inclusive education as indicated in the sustainable development goals. Vega-Hernández, Patino-Alonso and Galindo-Villardón (2018) explained that the integration of ICT into teaching improves the learning process. It also leads to the development of 21st-century skills, necessary for the survival of students in a rapidly changing labour market (Van Laar et al. 2017). Therefore, 21st-century academics are to use ICT for lecture preparation and delivery and self-paced and engaging learning opportunities for their students (Elçi 2019). An improvement on the extent of ICT use in teaching in Nigeria and other developing nations should be sought after, to enable graduates compete favourably with their counterparts the world over (Onwuagboke \& Singh 2016).

Evidence of ICT infusion in the educational sector proliferates with academics enjoying access to up-to-date information resources, course materials, communication with colleagues and expansion of learning preferences for students (Herath \& Hewagamage 2015). Research also shows that the use of specialised software such as the LMS becomes essential because it has features capable of improving learning outcomes and courses offered by universities (Marks, Maytha \& Rietsema 2016). Despite the suitability of ICT in teaching and learning, Lawrence and Tar (2018) expressed concern about the low attainment of the intended educational outcomes achieved so far. Studies emanating from educational scenarios especially from developing countries elucidate that several factors are responsible for the low integration of ICT in teaching (Okyere-Kwakye, Nor \& Ologbo 2016). According to Stephen et al. (2016), the obstacles to ICT integration into teaching are the high cost of computer hardware and software, inadequate and poor technological infrastructure and low budgetary allocation to higher education. 
Researchers further argue that academics who have positive belief towards technology can overcome these impediments (Ertmer et al. 1999).

Nnazor (2009) posit that those in charge of university management should create an environment that is enabling physically and psychologically, through restructuring so as to allow for all-out use of ICT in teaching. Previous scholars (Ansari \& Zuberi 2010; Edoru 2019; Porter \& Graham 2016) note that the prevalence of technological infrastructure would most meaningfully influence the use of ICTs by academics. Contrary to this standpoint, Afshari et al. (2009) argued that the use of ICT in any academia is influenced by several inter-related factors. Putting these factors into perspectives, the determinants of ICT use can be classified into four factors, namely environmental, technological, organisational and individual (Macharia \& Pelser 2014). However, some other scholars explained that insight into how these factors influence each other is highly desirable (Bower 2019). Beyond the understanding that ICT use is predicated on many inter-related factors, going by the submission of Adetimirin (2020), academics are to use ICTs, in particular the electronic resources in line with ethical guidelines to avoid being liable to offences such as copyright infringement and plagiarism. A study led by Ahmed and Kurshid (2015) demonstrated that individual attributes such as age, qualification and designation of academics significantly influence ICT use. The authors established that younger academics use ICT more than those who are older, but those in the professorial cadre use ICT more frequently than assistant professors. Lubis et al. (2017) added that the area of specialisation of academics also influences the use of ICT in teaching. David and Rahim (2012) researched into the impact of unified theory of acceptance and use of technology (UTAUT) on the use of ICT amongst academics in Adamawa State University, Nigeria. Findings revealed that perceived usefulness (PU) and perceived ease of use (PEOU) were the most influential factors associated with ICT use in teaching. However, the study of David and Rahim focussed on academics in a public university, where the use of ICT in teaching was not mandatory compared with many private owned institutions.

\section{Theoretical lens for the study}

There are many models and theories of information systems (ISs) that have been used to explain success factors for acceptance and the use of ICTs. But the one adopted as the theoretical lens for this study is the UTAUT proposed by Venkatesh et al. (2003). This is because of its suitability in educational settings, especially within Africa (Liebenberg, Benade \& Ellis 2018). Moreover, UTAUT is an integrated theory resulting from the constructs of eight individual theories of IS, namely theory of planned behaviour (TPB), technology acceptance model (TAM), innovation diffusion theory (IDT), social cognitive theory (SCT), theory of reasoned action (TRA), the model of PC utilisation (MPCU), combined TAM and TPB (C-TAM-TPB) and motivational model (MM) motivation theory. Unified theory of acceptance and the use of technology engages a more pragmatic approach in providing a better understanding of the factors that could predict the success of technology use than other IS theories and models (Samaradiwakara \& Gunawardena 2014). Similar studies (Kocaleva, Stojanovic \& Zdravev 2015; Ouedraogo 2017; Oye, Iahad \& Rahim 2014) have used the UTAUT model to examine the factors determining ICT acceptance and use. These studies demonstrate that the UTAUT consists of robust and valid parameters that may be used by researchers interested in understanding success factors for technology acceptance and use. Venkatesh et al. (2003) discussed four core constructs of UTAUT, namely performance expectancy (PE), effort expectancy (EE), social influence (SI) and facilitating conditions (FCs), which play a more prominent role in determining the success of ICT use in any organisation. Unified theory of acceptance and the use of technology also postulate that gender, age, experience and voluntariness of use act as moderating variables in determining the influence of the core constructs of UTAUT on technology adoption and use. This study focussed on PE, EE, SI and FC in determining the success of ICT use in an academic environment. The four core factors of UTAUT are described as follows:

- PE: It refers to 'the degree to which the user expects that using the system will help him or her to attain gains in job performance' (Venkatesh et al. 2003:447). It is analogous with PU, extrinsic motivation, job-fit and relative advantage.

- EE: It is defined as 'the degree of ease associated with the use of the system' (Venkatesh et al. 2003:450). It is related to PEOU, complexity and ease of use.

- SI: It refers to 'the degree to which an individual perceives that important others believe he or she should use the new system' (Venkatesh et al. 2003:451). It refers to the subjective norm in TRA, TAM, TPB and C-TAM-TPB, social factors in MPCU and images in IDT.

- FC: It denotes 'the degree to which an individual believes that an organisational and technical infrastructure exists to support use of the system' (Venkatesh et al. 2003:453).

\section{Research method}

The study was carried out in south-west Nigeria. South-west Nigeria is made up of six states: Lagos, Ogun, Oyo, Osun, Ondo and Ekiti states. Two universities, the University of Ibadan (UI), a public university in Oyo state, and Covenant University (CU), a private university situated in Ogun state, were purposively selected as the study sites. The UI was founded in 1948, whereas CU was established in 2002 as a result of the reformation in the educational sector in Nigeria. The UI was selected because it is the first and oldest public university in Nigeria, and both universities have made laudable efforts in ICT investment. Academics from three faculties (Arts, Science and Technology) that comprise the majority of disciplines that are common to both universities were purposively chosen. 
A mixed method approach consisting of a survey and semi-structured interview were used to collect quantitative and qualitative data. The quantitative aspect was dominant and the qualitative was engrained within it. The mixed method approach was found to be the most suitable for this study's purpose as it helps to minimise the shortcomings of both approaches and provide a better understanding of research questions (Creswell 2014). This view is supported by Oshinaike and Adekunmisi (2012) who also adopted the mixed-methods research approach. The population of the study was 502 academics for the UI and for CU it is 230, making a total of 732 academics from both universities. By using Israel's (1992) sample sizes table, 267 academics made up the sample size for this study. Respondents in the survey were chosen by using the systematic random sampling technique. The questionnaire was adapted from Venkatesh et al. (2003) and Birch and Irvine (2009). It comprises items of the UTAUT and four main constructs, namely PE, EE, SI and FC, with minimal rephrasing to suit the purpose of the study. Prior to data collection, the internal consistency and reliability of the items of the instrument developed for this research were determined in a pilot study conducted at the University of Lagos amongst 30 academics and 3 university management staff, chosen because of the similarity in characteristics with the sample population. The Cronbach alpha results obtained were 0.97 for PE, 0.80 for EE, 0.74 for SI and 0.74 for FC.

A total of 183 questionnaires were distributed at the UI, 162 were returned, but only 131 were found suitable for the purpose of data analysis. The researcher administered 84 questionnaires at $\mathrm{CU}$ and all of them were returned and found useful for the purpose of data analysis. Overall, 267 questionnaires were distributed, and 246 were returned out of which 215 questionnaires were found suitable for data analysis. For the qualitative study, an interview guide was used for consistency of questions and responses. The interviewees were deans of the selected faculties, the director for centre for ICT and the university librarian, and data were collected through the census from 10 out of 11 participants. This category of people were considered key informants because they are involved in strategic decision-making, policy development and implementation in the university. The interview reponses were recorded by using a research diary and a handheld device with due consent of the interviewees. The quantitative data were analysed by using the Statistical Package for Social Sciences (SPSS) software to generate both descriptive (frequencies and percentages) and inferential statistics. The semistructured interview data were analysed by using content analysis. An ethical guideline that involved the use of informed consent, voluntariness of participation in the study, protection of respondents' identities and freedom to withdraw from the study at any time as proposed by Creswell (2014) was adopted for this study.

\section{Ethical consideration}

An ethical guideline that involved use of informed consent, voluntariness of participation in the study, protection of respondents' identities and freedom to withdraw from the study at any time as proposed by Creswell (2014) was adopted for this study (Ethical Clearance Number: HSS/1484/014D).

\section{Results \\ Demographic profile of respondents}

The study found that more male respondents participated in the study with $(95 \%$ or $72.5 \%)$ from the UI and 62 $(73.8 \%)$ from CU than female academics. A majority of the respondents were in the age of 36-46 years with the UI having a proportion of $67(51.1 \%)$ and CU had 45 (53.6\%), whereas those between 58 and 68 years had the least proportion. Results further showed that the designation of the respondents ranged from assistant lecturers to those in the professorial cadre. A majority of the academics were in the lecturer grade II category with $36(27.5 \%)$ at the UI and $23(27.5 \%)$ from CU followed by assistant lecturer cadre. Further findings showed that a majority of the respondents with 91 (69.5\%) from the UI and 37 (44.0\%) from CU had a $\mathrm{PhD}$ degree as their highest educational qualification. The study found that a majority of the respondents are from the Faculty of Science/Natural and Applied Science, with the UI having $64(48.8 \%)$ whereas CU had 39 (46.4\%) as shown in Table 1. The findings showed considerable combination across demographic variables; hence, data collected can be regarded as reliable for the purpose of this study.

TABLE 1: Demographic characteristics of respondents $(N=215)$.

\begin{tabular}{|c|c|c|c|c|}
\hline \multirow{2}{*}{$\begin{array}{l}\text { Demographic characteristics of } \\
\text { respondents }\end{array}$} & \multicolumn{2}{|c|}{ University of Ibadan } & \multicolumn{2}{|c|}{ Covenant university } \\
\hline & Frequency & $\%$ & Frequency & $\%$ \\
\hline \multicolumn{5}{|l|}{ Gender } \\
\hline Male & 95 & 72.5 & 62 & 73.8 \\
\hline Female & 36 & 27.5 & 22 & 26.2 \\
\hline \multicolumn{5}{|l|}{ Age (years) } \\
\hline 25-35 & 16 & 12.2 & 23 & 27.4 \\
\hline $36-46$ & 67 & 51.1 & 45 & 53.6 \\
\hline $47-57$ & 36 & 27.5 & 10 & 11.9 \\
\hline $58-68$ & 12 & 9.2 & 6 & 7.1 \\
\hline \multicolumn{5}{|l|}{ Designation } \\
\hline Professor & 9 & 6.9 & 4 & 4.9 \\
\hline Reader/Associate Professor & 15 & 11.4 & 5 & 5.9 \\
\hline Senior Lecturer & 27 & 20.6 & 15 & 17.9 \\
\hline Lecturer I & 24 & 18.3 & 9 & 10.7 \\
\hline Lecturer II & 36 & 27.5 & 23 & 27.4 \\
\hline Assistant Lecturer & 20 & 15.3 & 28 & 33.3 \\
\hline \multicolumn{5}{|l|}{ Highest educational qualification } \\
\hline PhD & 91 & 69.5 & 37 & 44.0 \\
\hline MSc & 27 & 20.6 & 40 & 47.6 \\
\hline MA & 11 & 8.4 & 4 & 4.8 \\
\hline Others & 2 & 1.5 & 3 & 3.6 \\
\hline \multicolumn{5}{|l|}{ Faculty/school } \\
\hline Arts/School of Leadership & 33 & 25.2 & 7 & 8.4 \\
\hline Technology/Engineering & 34 & 26.0 & 38 & 45.2 \\
\hline $\begin{array}{l}\text { Science/Natural and Applied } \\
\text { Science }\end{array}$ & 64 & 48.8 & 39 & 46.4 \\
\hline
\end{tabular}

PhD, Doctor of Philosophy; MSc, Master of Science; MA, Master of Arts. 


\section{Findings: Descriptive analysis Performance expectancy}

Performance expectancy was measured by using five items out of which a descriptive analysis of the average score of the statement 'I find ICTs useful in teaching' with the highest mean score, and the least deviation from the mean (0.799) followed by 'ICTs enable me to accomplish tasks such as teaching more efficiently' with $\bar{x}=4.52$ and $S D=0.815$ and 'use of ICTs enhances my teaching in terms of content and delivery' with $\bar{x}=4.51$ and $S D=$ with $\bar{x}=4.52$ and $S D=0.815$ indicate that the use of ICT in teaching is beneficial to academics in both private and public universities.

\section{Effort expectancy}

The mean value of responses to the variable EE showed that 'learning to use ICTs is easy for me' $(\bar{x}=4.07$ and standard deviation 0.971); 'ICTs are generally easy to use' $(\bar{x}=4.00$ and $S D=0.985)$; and 'I do not find the use of ICTs in my teaching a frustrating endeavour' $(\bar{x}=3.88$ and $S D=0.989$ ) had the highest means. The results indicate that more academics perceive ICTs to be easy to use.

\section{Social influence}

Social influence was measured with four items out of which the statement 'people who are important to me such as my Dean, HOD and my colleagues think I should use ICTs in my teaching' $(\bar{x}=3.85$ and $S D=1.167)$ had the highest mean. This was followed by the statement 'my students particularly think I should use ICTs in my teaching' with $\bar{x}=3.87$ and $S D=1.117$.

\section{Facilitating conditions}

With a mean score of 3.64 and standard deviation of 1.331 , the respondents indicated that 'my institution should make more ICT resources (such as computers, projectors, internet

TABLE 2: $F$-statistic test.

\begin{tabular}{llccccc}
\hline Institution & Model & Sum of square & $\boldsymbol{d f}$ & Mean square & $\boldsymbol{F}$ & Sig. \\
\hline University of & Regression & 203.245 & 4 & 50.811 & - & - \\
Ibadan & Residual & 1695.488 & 126 & 13.456 & - & - \\
& Total & 1898.734 & 130 & - & 3.776 & 0.006 \\
Covenant & Regression & 1361.747 & 4 & 340.437 & - & - \\
University & Residual & 8122.718 & 79 & 102.819 & - & - \\
& Total & 9484.465 & 83 & - & 3.311 & 0.015 \\
\hline
\end{tabular}

$d f$, degrees of freedom; Sig., significance; $F$, Fisher. connectivity, LMS, e-resources, etc.) available for use in the department/faculty'. This was followed by the statement 'my institution has people in ICT section who are available to provide assistance with difficulty on the use of ICTs' with $\bar{x}=3.54$ and $S D=1.217$.

\section{F-statistic test}

The $F$-test allows for evaluation of two competing regression models in their ability to explicate the variance in the dependent variable. Therefore, to determine if the association between the independent variables (PE, EE, SI and FC) and the dependent variable (ICT use in teaching) is statistically significant, the $p$ value was taken into consideration. Table 2 shows that for academics at the UI with $F(4,126)=3.776, p=0.006$ and at $\mathrm{CU}$ with $F(4,79)=3.311, p=0.015$, regression model is significantly better at predicting the use of ICT in teaching at the UI and CU from PE, EE, SI and FC with $p<0.05$.

\section{Regression analysis}

Table 3 shows the results that only FCs $(\beta=-0.345, t=-3.221$, $p=0.002$ ) have significant influence on the use of ICT in teaching at the UI, whereas EE, SI and PE are poor predictors of the use of ICT in teaching by academics at the UI. However, both EE $(\beta=0.380, t=3.116, p=0.003)$ and FCs $(\beta=-0.281$, $t=-2.327, p=0.023)$ have significant influence on the use of ICT by academics in CU. Findings also reveal that PE and SI are poor predictors of the use of ICT in teaching in CU.

To complement these findings, the deans, the directors of Centre for Information and Technology System (CITS) and the two library directors (university librarians) were asked to express their thoughts on factors they consider most imperative for success in ICT use in teaching. This elicited several responses as shown in Table 4.

\section{Test of hypothesis Hypothesis 1}

Demographic variables (age, gender and academic qualification) have no effect on the determinants of ICT use in teaching amongst academics.

Spearman's correlation coefficient was used for determining the relationship between the demographic variables (age, gender and academic qualification) and the determinants of ICT use.

TABLE 3: Regression result of underlying success factors for information and communication technology use in teaching.

\begin{tabular}{|c|c|c|c|c|c|c|}
\hline \multirow[t]{2}{*}{ Model } & \multicolumn{3}{|c|}{ University of Ibadan } & \multicolumn{3}{|c|}{ Covenant University } \\
\hline & $\begin{array}{l}\text { Standardised } \\
\text { coefficients: Beta }\end{array}$ & $t$ & Sig. & $\begin{array}{c}\text { Standardised } \\
\text { coefficients: Beta }\end{array}$ & $t$ & Sig. \\
\hline Constant & - & 3.186 & 0.002 & - & 2.105 & 0.039 \\
\hline Performance expectancy & 0.092 & 0.75 & 0.455 & -0.105 & -0.842 & 0.403 \\
\hline Effort expectancy & -0.021 & -0.156 & 0.876 & 0.38 & 3.116 & $0.003 \dagger$ \\
\hline Social influence & 0.239 & 1.835 & 0.069 & -0.05 & -0.423 & 0.673 \\
\hline Facilitating conditions & -0.345 & -3.221 & $0.002 \dagger$ & -0.281 & -2.327 & $0.023 \dagger$ \\
\hline
\end{tabular}

$\dagger$, significant influence.

Note: Dependent Variable: ICT use in teaching.

Sig., significance. 
At the UI, the correlation between age and EE $(r=0.194, N=$ 131, $p=0.026)$ was significant. This implies a positive relationship between age and $\mathrm{EE}$. A positive relationship also exists between age and FC ( $r=0.232, N=131, p=0.008)$. Therefore, age had an effect on EE and FC amongst academics at the UI. However, the relationship was not significant between gender and all the determinants of ICT use, as well as academic qualification and all the determinants of ICT use (PE, EE, SI and FC) with $p>0.05$ (see Table 5). Further findings show that age had a statistically significant correlation with SI amongst academics at $\mathrm{CU}(r=-0.236, N=84, p=0.031)$. This implies that out of all the demographic factors, age emerged as the only variable that had an effect on FC amongst academics at UI. Age also had an effect on SI amongst academics at CU (see Table 5).

\section{Discussion of findings}

This section discusses the major findings of the study.

\section{Facilitating condition}

The results of the study reveal that FC is a significant determinant of ICT use in teaching at the UI. Findings also show that both EE and FC are the major determinants of ICT use amongst academics in CU. The results from this study suggest that $\mathrm{EE}$ and FC are the variables that significantly influence academics' use of ICTs in teaching. However, FC is the most important underlying factor for ICT use in teaching amongst academics in a public university, whereas EE and FC are requisite for ICT use amongst academics in private university. Similar to this finding, Kocaleva et al. (2015) found that FC and EE have a stronger influence on technology use. Facilitating condition is the degree to which an individual believes that organisational and technical infrastructure exist to support the use of technology (Venkatesh et al. 2003).
Going by the submission of Alshmrany and Wilkinson (2017), FC is a supportive environment, which reduces any difficulty in technology adoption and use. In institutions of learning, FCs are availability of technical assistance, infrastructure, hardware and software (Bingimlas 2009) in any organisation. Facilitating condition, according to Yoo, Han and Huang (2012), usually serves as a source of motivation in technology adoption and use. In this study, another important finding is that age had an effect on EE and FC amongst academics at UI. This implies that academics who are older put more emphasis on FCs than those who are younger.

\section{Effort expectancy}

It was found that academics from $\mathrm{CU}$ perceived $\mathrm{EE}$, aside from FC to be a fundamental determinant of ICT use. The results further confirmed that EE, a construct analogous to ease of use in TAM, has a strong influence on ICT use. This result is not unexpected, as previous studies (Venkatesh et al. 2003) pointed out that EE is a subset of FC. The strength of this construct in predicting technology use in other contextual settings such as e-government, e-commerce and healthcare has been demonstrated in various empirical studies (Ozkan \& Kanat 2011; Yang 2010). As EE had influence on ICT use in teaching, Haslaman, Mumcu \& Usluel (2008) pointed out the need for an internal helpdesk, whose job will be provision of support services to academics on the use of ICT in teaching. The strength of the UTAUT constructs in predicting technology acceptance and use is further supported by the result of this study.

Interviews with the deans, the directors of CITS and the two library directors (university librarians) revealed that management at both private and public universities are aware of the major factors influencing the use of ICT in

TABLE 4: Synopsis of interview responses on underlying success factors for information and communication technology use $(N=10)$.

\begin{tabular}{|c|c|c|c|}
\hline Respondent & Institution & Category of respondent & Response \\
\hline $\mathrm{R} 2$ & UI & Dean of Faculty & $\begin{array}{l}\text { '... of course, institutional policy is very important because if you are in an organisation, whatever your belief is, } \\
\text { you must abide by the policy and regulations of the institution where you work'. }\end{array}$ \\
\hline R3 & UI & Dean of Faculty & $\begin{array}{l}\text { '... it is more of infrastructural support than any of these factors put together, if the technological infrastructures } \\
\text { are not there, ICT adoption and use is not possible in the first instance'. }\end{array}$ \\
\hline R6 & $\mathrm{CU}$ & Dean of Faculty & 'I would attribute these factors to funding and institutional policy'. \\
\hline R4 & UI & Dean of Faculty & '... to me, institutional policy is of no value if it is not backed up with fund'. \\
\hline R8 & CU & Director, CITS & $\begin{array}{l}\text { '... organisational support is an imperative factor for ICT use. For instance in this institution, university management } \\
\text { ensures that we have access to electricity } 24 / 7 \text { through a private patnership'. }\end{array}$ \\
\hline R10 & $\mathrm{CU}$ & University Librarian & $\begin{array}{l}\text { 'If I have to do a ranking of all the factors that could serve as underlying factors for the use of ICT in teaching, first is } \\
\text { university policy, then technological infrastructure, followed by simplicity of use'. }\end{array}$ \\
\hline
\end{tabular}

UI, University of Ibadan; CU, Covenant University, ICT, information and communication technology.

TABLE 5: Correlation analysis between demographic characteristics and underlying factors of information and communication technology use in teaching.

\begin{tabular}{|c|c|c|c|c|c|c|c|c|c|}
\hline \multirow[t]{2}{*}{ University } & \multirow{2}{*}{$\begin{array}{l}\text { Demographic } \\
\text { characteristics }\end{array}$} & \multicolumn{2}{|c|}{ Performance expectancy } & \multicolumn{2}{|c|}{ Effort expectancy } & \multicolumn{2}{|c|}{ Social influence } & \multicolumn{2}{|c|}{ Facilitating conditions } \\
\hline & & $r$ & $p$ & $r$ & $p$ & $r$ & $p$ & $r$ & $p$ \\
\hline \multirow{3}{*}{$\begin{array}{l}\text { University of Ibadan } \\
(N=131)\end{array}$} & Gender & -0.055 & 0.531 & 0.048 & 0.584 & -0.070 & 0.436 & -0.004 & 0.963 \\
\hline & Age & 0.012 & 0.890 & 0.194 & $0.026 \dagger$ & 0.094 & 0.288 & 0.232 & $0.008 \dagger$ \\
\hline & Highest qualification & 0.128 & 0.144 & 0.113 & 0.200 & -0.060 & 0.499 & -0.023 & 0.794 \\
\hline \multirow{3}{*}{$\begin{array}{l}\text { Covenant University } \\
(N=84)\end{array}$} & Gender & 0.064 & 0.566 & 0.176 & 0.109 & 0.129 & 0.242 & 0.168 & 0.126 \\
\hline & Age & -0.213 & 0.052 & 0.088 & 0.428 & -0.236 & $0.031 \dagger$ & -0.147 & 0.183 \\
\hline & Highest qualification & 0.113 & 0.307 & 0.011 & 0.921 & -0.063 & 0.570 & -0.149 & 0.177 \\
\hline
\end{tabular}

$\dagger$, positive relationship between the variables. 
teaching and learning. One of the deans of faculty totally opines that:

... it is more of infrastructural support than any of these factors put together, if the technological infrastructures are not there, ICT adoption and use is not possible in the first instance instance!' (R3, UI, Dean of Faculty)

Overall, the qualitative aspect of this study showed that institutional policy, technological infrastructure, simplicity of use, fund and organisational support were requisites for ICT use. Related studies (Al-Mobaideen 2009) found similar factors in Jordanian universities, indicating that the concerns raised by respondents in Nigerian universities about critical success factors for ICT use in teaching are largely similar to those of scholars from other parts of the world.

\section{Performance expectancy}

Findings showed that PE had no significant influence on the use of ICT in teaching amongst academics in both public and private universities. The descriptive analysis showed that out of all of the individual items used in measuring the construct academics from both UI and CU, the statement 'I find ICTs useful in teaching' emerged with the highest mean score and the least deviation from the mean. This finding implies that academics are not disputing the usefulness of ICT in teaching. In the context of this study, academics in both private and public universities do not attach much importance to PE as a decisive factor in ICT use.

\section{Social influence}

Social influence is defined by Venkatesh et al. (2003:451) as: 'the degree to which an individual perceives that important others believe he or she should use the new system'. The findings of this study showed that SI had no significant influence on the ICT use in teaching. The result is divergent from previous research, which found SI to have a significant relationship with behavioural intention to use technology (Moussaïd et al. 2013). Further findings revealed that age had a significant correlation with SI amongst academics in a private university (CU). This finding suggests that the older academics are more likely to believe that their image and reputation will improve with the use of ICT in teaching (Rogers 2003).

\section{Conclusion and recommendations}

Today's academics must use ICTs in teaching to better position themselves within the learning curve as facilitators and not the sole custodians of knowledge. In finding support for ICT use in teaching, the possibility lies in unwavering effort towards provision of an enabling environment. This article concludes that stakeholders in higher institutions should give adequate attention to these underlying factors: FCs and EE for optimal success of ICT use in teaching.

\section{Implication of the study for policy makers}

The implications of these findings is that stakeholders in higher institutions should be more involved in helping academics to develop a greater sense of ICT use in teaching through provision of a supportive environment, most especially provision of infrastructure, hardware, software, technical assistance and regular training. The study makes significant contribution to IS theory by revealing the analytical power of the UTAUT in determining the underlying success factors for ICT use in an educational setting.

\section{Limitation of study}

The limitation of this study lies in its inability to include academics from higher institutions in other geopolitical zones in Nigeria, and as such, the results cannot be applied to settings other than areas where the study was conducted, except when replicated over time. Future studies should include other academics from other disciplinary backgrounds and from universities other than those used in this study.

\section{Acknowledgements}

This article reports on part of the findings of a doctoral study that was completed at the University of KwaZulu-Natal in 2016.

\section{Competing interests}

The authors have declared that no competing interests exist.

\section{Authors' contributions}

A.O.A. carried out the research for her PhD study and S.M. supervised the PhD research.

\section{Funding information}

This research received no specific grant from any funding agency in the public, commercial or not-forprofit sectors.

\section{Data availability statement}

Data sharing is not applicable to this article as no new data were created or analysed in this study.

\section{Disclaimer}

The views and opinions expressed in this article are those of the authors and do not necessarily reflect the official policy or position of any affiliated agency of the authors.

\section{References}

Adetimirin, A., 2020, 'Technology adoption for teaching: The ethical considerations' in Handbook of research on diverse teaching strategies for the technology-rich classroom, pp. 70-78, IGI Global, Hershey, PA.

Afshari, M., Bakar, K.A., Luan, W.S., Samah, B.A. \& Fooi, F.S., 2009, 'Factors affecting teachers' use of information and communication technology', Online Submission 2(1), 77-104. 
Ahmed, H. \& Kurshid, F., 2015, 'Use of Information and Communication Technology (ICT) among public and private sector universities in teaching and learning process', Scholedge International Journal of Multidisciplinary \& Allied Studies 2(4) process', Scholedge International Journal of M
25-36. https://doi.org/10.2139/ssrn.2583373

Alhabeeb, A. \& Rowley, J., 2017, 'Critical success factors for eLearning in Saudi Arabian universities', International Journal of Educational Management 31(2), 131-147. https://doi.org/10.1108/IJEM-01-2016-0006

Alharbi, S. \& Drew, S., 2014, “'Using the technology acceptance model in understanding academics" behavioural intention to use learning management systems', International Journal of Advanced Computer Science and Applications 5(1) 143-155. https://doi.org/10.14569/IJACSA.2014.050120

Al-Mobaideen, H.O., 2009, 'Assessing information and communication technology in Jordanian universities: Building critical success factors' (CSF) model of ICT diffusion', Doctoral dissertation, Leeds Metropolitan University.

Almpanis, T., 2015, 'Staff development and institutional support for technology enhanced learning in UK universities', Electronic Journal of E-Learning 13(5), 366-375.

Alshmrany, S. \& Wilkinson, B. 2017, 'Factors influencing the adoption of ICT by teachers in primary schools in Saudi Arabia', Education (Mohe) 8(12), 143-156. https://doi.org/10.14569/IJACSA.2017.081218

Ansari, M.N. \& Zuberi, B.A., 2010, 'Use of electronic resources among academics at the University of Karachi', Library Philosophy and Practice, viewed 16 April 2019 from https://digitalcommons.unl.edu/libphilprac/385.

Barrette, C.M., 2015, 'Usefulness of technology adoption research in introducing an online workbook', System 49, 133-144. https://doi.org/10.1016/j.system.2015.01.005

Bingimlas, K.A., 2009, 'Barriers to the successful integration of ICT in teaching and learning environments: A review of the literature', Eurasia Journal of Mathematics, Science \& Technology Education 5(3), 235-245. https://doi.org/10.12973/ejmste/75275

Birch, A. \& Irvine, V., 2009, " "Preservice teachers" acceptance of ICT integration in the classroom: Applying the UTAUT model', Educational Media International 46(4), 295-315. https://doi.org/10.1080/09523980903387506

Bower, M., 2019, 'Technology-mediated learning theory', British Journal of Educational Technology 50(3), 1035-1048. https://doi.org/10.1111/bjet.12771

Buchanan, T., Sainter, P. \& Saunders, G., 2013, 'Factors affecting faculty use of learning technologies: Implications for models of technology adoption', Journal of Computing in Higher Education 25(1), 1-11. https://doi.org/10.1007/s12528-013-9066-6

Creswell, J.W., 2014, Research design: Qualitative, quantitative and mixed methods approaches, 4th edn., Sage, Thousand Oaks, CA

David, O.N. \& Rahim, N.Z.A., 2012, 'The impact of UTAUT model and ICT theoretical framework on university academic staff: Focus on Adamawa state university Nigeria', International Journal of Computers \& Technology 2(2), 102-111. https:// doi.org/10.24297/ijct.v2i2b.2640

Edoru, M.J., 2019, Information and communication technology in Ugandan higher education, Kabale University, Kabale.

Ertmer, P.A., Paul, A., Molly, L., Eva, R. \& Denise, W., 1999, 'Examining teachers' beliefs about the role of technology in the elementary classroom', Journal of Research on Computing in Education 32(1), 54-72.

Elçi, A., 2019, 'Faculty development centers for digital teaching and learning: Implementation of institutional strategy and infrastructure', in Handbook of research on faculty development for digital teaching and learning, pp. 417-437, IGI Global, Hershey, PA.

Gambari, A.I. \& Okoli, A., 2007, 'Availability and utilization of information and communication technology (ICT) facilities in higher institutions in Niger State Nigeria', Information Technology 4(1), 34-46. https://doi.org/10.4314/ict.v4i1.31973

Haslaman, T., Mumcu, F.K. \& Usluel, Y.K., 2008, 'Integration of ICT into the teachinglearning process: Toward a unified model', in Proceedings of World Conference on Educational Multimedia, Hypermedia and Telecommunications 2008, pp. 2384-2389, AACE, Chesapeake, VA

Herath, H.M. \& Hewagamage, C., 2015, 'Analysis of ICT usage for the teaching and learning process by the academics', International Journal of Computer and Information Technology 4(05), 803-808.

Ibara, E.C., 2014, 'Information and communication technology integration in the Nigerian education system: Policy considerations and strategies', Educational Planning 21(3), 5-18.

Israel, G.D., 1992, Determining sample size, University of Florida Cooperative Extension Service, Institute of Food and Agriculture Sciences, EDIS, viewed 16 April 2019, from http://sociology.soc.uoc.gr/.

Kocaleva, M., Stojanovic, I. \& Zdravev, Z., 2015, 'Model of e-learning acceptance and use for teaching staff in higher education institutions', International Journal of Modern Education and Computer Science (IJMECS) 7(4), 23-31. https://doi. org/10.5815/ijmecs.2015.04.03

Lawal, L.S., Chatwin, C.R. \& Hasan, R., 2018, 'The communications satellite industry as an element in Nigeria's attempt to modernise its economy and society', International Journal of African and Asian Studies 51, 30-39.

Lawrence, J.E. \& Tar, U.A., 2018, "Factors that influence teachers" adoption and integration of ICT in teaching/learning process', Educational Media International 55(1), 79-105. https://doi.org/10.1080/09523987.2018.1439712

Liebenberg, J., Benade, T. \& Ellis, S., 2018, 'Acceptance of ICT: Applicability of the Unified Theory of Acceptance and Use of Technology (UTAUT) to South African students', The African Journal of Information Systems 10(3), 160-173.

Lubis, A.H., Zulkarnain, S., Idrus, S. \& Asiah, S., 2017, 'The use of ICT among university's lecturers in Medan, Indonesia: A comparative study', Journal of Human Development and Communication 6, 63-76.

Macharia, J.K. \& Pelser, T.G., 2014, 'Key factors that influence the diffusion and infusion of information and communication technologies in Kenyan higher education', Studies in Higher Education 39(4), 695-709. https://doi.org/10.1080/ 03075079.2012.729033
Marks, A., Maytha, A.A. \& Rietsema, K., 2016, 'Learning management systems: A shift toward learning and academic analytics', International Journal of Emerging Technologies in Learning (IJET) 11(04), 77-82. https://doi.org/10.3991/ijet. v11i04.5419

Matthew, D., Joro, I.D. \& Manasseh, H., 2015, 'The role of information communication technology in Nigeria educational system', International Journal of Research in Humanities and Social Studies 2(2), 64-68.

Mbatha, B.T., Ocholla, D.N. \& Roux, J.L., 2011, 'Diffusion and adoption of ICTs in selected government departments in KwaZulu-Natal, South Africa', Information Development 27(4), 251-263. https://doi.org/10.1177/0266666911424864

Miller, E.R., 2017, Predicting the use of instructional technology among community college instructors: An extension of the Technology Acceptance Model (TAM) University of South Alabama, Mobile, AL.

Moussaïd, M., Kämmer, J.E., Analytis, P.P. \& Neth, H., 2013, 'Social influence and the collective dynamics of opinion formation', PLOS One 8(11), e78433. https://doi. org/10.1371/journal.pone.0078433

Njoku, C., 2015, 'Information and communication technologies to raise quality of teaching and learning in higher education institutions', International Journal of Education and Development using ICT 11(1), 122-147.

Nnazor, R., 2009, 'A conceptual framework for understanding use of information and communication technology in teaching in universities', International Journal of Instructional Technology \& Distance Learning 6(1), 47-58.

Ntemana, T.J. \& Olatokun, W., 2012, 'Analyzing the influence of diffusion of innovation attributes on lecturers' attitudes toward information and communication technologies', Human Technology 8(2), 179-197. https://doi.org/10.17011/ht/ urn.201211203034

Okon, A.E., Ngulube, P. \& Onyancha, B., 2014, 'Accessibility and utilization of electronic information resources for research by academic staff at selected Nigerian universities between 2005 and 2012', International Information \& Library Review 46(1-2), 51-60. https://doi.org/10.1080/10572317.2014.922858

Okyere-Kwakye, E., Nor, K.M. \& Ologbo, A.C., 2016, 'Technology acceptance: Examining the intentions of Ghanaian teachers to use computer for teaching', African Journal of Library, Archives \& Information Science 26(2), 119-132.

Onwuagboke, B.B.C. \& Singh, T.K.R., 2016, 'Faculty attitude and use of ICT in instructional delivery in tertiary institutions in a developing nation', International
Journal of Research Studies in Educational Technology 5(1), 77-88. https://doi. Journal of Research Studies in
org/10.5861/ijrset.2016.1428

Oshinaike, A.B. \& Adekunmisi, S.R., 2012, Use of multimedia for teaching in Nigerian university system: A case study of university of Ibadan, viewed 16 April 2019. from http://www.webpages.uidaho.edu/*mbolin/oshinaike-adekunmisi.htm.

Ouedraogo, B., 2017, 'Model of Information and Communication Technology (ICT) acceptance and use for teaching staff in sub-saharan Africa public higher education institutions', Higher Education Studies 7(2), 101-118. https://doi. org/10.5539/hes.v7n2p101

Oye, N.D., lahad, N.A. \& Rahim, N.A., 2014, 'The history of UTAUT model and its mpact on ICT acceptance and usage by academicians', Education and Information Technologies 19(1), 251-270. https://doi.org/10.1007/s10639-012-9189-9

Ozkan, S. \& Kanat, I.E., 2011, 'e-Government adoption model based on theory of planned behavior: Empirical validation', Government Information Quarterly 28(4), 503-513. https://doi.org/10.1016/j.giq.2010.10.007

Porter, W.W. \& Graham, C.R., 2016, 'Institutional drivers and barriers to faculty adoption of blended learning in higher education', British Journal of Educational Technology 47(4), 748-762. https://doi.org/10.1111/bjet.12269

Rogers, M.E., 2003, Diffusion of Innovations (5th ed.), Free Press, New York, NY.

Samaradiwakara, G.D.M.N. \& Gunawardena, C.G., 2014, 'Comparison of existing technology acceptance theories and models to suggest a well improved theory/ model', International Technical Sciences Journal 1(1), 21-36.

Stephen, E.D., Yakubu, M., Omale, A. \& Musa, A., 2016, 'Utilization of information and communication technology resources by academics staff and students in colleges of education in Nigeria', International Journal of Academic Library and Information Science 4(1), 1-10.

Van Laar, E., Van Deursen, A.J., Van Dijk, J.A. \& De Haan, J., 2017, 'The relation between 21stcentury skills and digital skills: A systematic literature review',
Computers in Human Behavior 72(1), 577-588. https://doi.org/10.1016/j. Computers in Hun
chb.2017.03.010

Vega-Hernández, M.C., Patino-Alonso, M.C. \& Galindo-Villardón, M.P., 2018 'Multivariate characterization of university students using the ICT for learning', 'Multivariate characterization of university students using the ICT for learning',
Computers \& Education 121(1), 124-130. https://doi.org/10.1016/j.compedu. 2018.03.004

Venkatesh, V., Morris, M.G., Davis, G.B. \& Davis, F.D., 2003, 'User acceptance of information technology: Toward a unified view', MIS Quarterly 27(3), 425-478. https://doi.org/10.2307/30036540

Willis, C., Kestell, C., Grainger, S. \& Missingham, D., 2013, 'Encouraging the adoption of education technology for improved student outcomes', Australasian Journal of Engineering Education 19(2), 109-117. https://doi.org/10.7158/D12 012.2013.19.2

Yang, K., 2010, 'Determinants of US consumer mobile shopping services adoption: Implications for designing mobile shopping services', Journal of Consumer Marketing 27(3), 262-270. https://doi.org/10.1108/07363761011038338

Yoo, S.J., Han, S.H. \& Huang, W., 2012, 'The roles of intrinsic motivators and extrinsic motivators in promoting e-learning in the workplace: A Case from South Korea' Computers in Human Behavior 28(3), 942-950. https://doi.org/10.1016/j chb.2011.12.015

Yushau, B. \& Nannim, F.A., 2018, 'ICT facilities and their utilization for educational purposes in Nigerian universities: A review of literatures from 2004 to $2018^{\prime}$, ATBU purposes in Nigerian universities: A review of literatures from
Journal of Science, Technology and Education 6(1), 237-263. 